\title{
The influence of photographs as a visual stimuli on traditional knowledge of two medicinal tree species
}

\author{
A influência de fotografias como estímulo visual sobre o conhecimento tradicional \\ de duas espécies arbóreas medicinais \\ M. N. R. Coêlhoํ; A. C. Baptistel ${ }^{1}$; J. R. Sousa Júnior²; J. M. Monteiro²* \\ ${ }^{1}$ Universidade Federal do Piauí, Campus Profa. Cinobelina Elvas, Planalto Horizonte, 64900-000, Bom Jesus, PI, \\ Brazil \\ ${ }^{2}$ Universidade Federal do Piauí, Campus Amílcar F. Sobral, Departamento de Biologia, 64800-000, Floriano, PI, \\ Brazil \\ *juliommonteiro@ufpi.edu.br \\ (Recebido em 14 de agosto de 2019; aceito em 31 de maio de 2020)
}

\begin{abstract}
This study aimed to verify the efficiency of photographs as visual stimuli and the knowledge of the Santo Antonio community, Piauí, Northeast Brazil, on two species widely used in local therapy. Semi-structured interviews were conducted using the checklist/inventory method which consisted in offering clear pictures to informants. Furthermore, local knowledge was also analyzed using quantitative measurements. The present study cited 16 uses for amburana (A. cearenses) and ten uses for mangabeira (L. replicata); moreover, the use of visual stimuli proved to be inefficient with respect to the recognition of these two tree species $(A$. cearenses and L. replicata) in the studied community. The results obtained, despite the knowledge of only two species, can add to the information provided about the specific domain of knowledge regarding the medicinal plants, because the selected species are very popular in the region.

Keywords: Amburana cearenses, Lafoensia replicata, checklist/interview.
\end{abstract}

O presente trabalho objetivou verificar a eficiência de fotografias como estímulo visual e o conhecimento da comunidade de Santo Antonio, Piauí, Nordeste do Brasil, sobre o conhecimento de duas espécies muito utilizadas na terapêutica local. Entrevistas semi-estruturadas foram realizadas e tiveram início com base no método "cheklist/entrevista" que consistiu na oferta de fotografias nítidas aos informantes. Além disso, o conhecimento local também foi analisado através de medidas quantitativas. No presente estudo foram citados 16 usos para a amburana (A. cearenses) e dez usos para a mangabeira (L. replicata), e ainda, o estímulo visual selecionado mostrou-se ineficiente para o reconhecimento das duas espécies arbóreas (L. replicata. e A. cearensis) na comunidade estudada. Ademais, os resultados obtidos, mesmo considerando o conhecimento sobre apenas duas espécies, podem somar às informações fornecidas sobre o domínio específico do conhecimento concernente às plantas medicinais, uma vez que as espécies selecionadas são muitos populares na região.

Palavras chave: Amburana cearenses, Lafoensia replicata, cheklist/entrevista.

\section{INTRODUCTION}

Ethnobotany, as a scientific discipline, seeks to study the dynamic interactions between plants and humans; also seeking to elucidate the existence of patterns of use and collection of plant species. In the last decades, the number of studies has increased, incorporating techniques and tools from disciplines like anthropology and ecology, and thus, can respond to a greater number of scientific issues [1].

These studies with scientific interest done with groups of people can obtain information using visual stimuli as an additional strategy, guaranteeing unilateral understanding that the interviewer and the interviewee are addressing the same object [2]. According to Medeiros et al. (2010) [2] some studies applied different visual stimulation techniques, for example: (a) Individuals in situ, whose stimuli demonstrates the plant in its natural environment, and thus facilitating its identification; (b) Dried specimen, this method consists of showing parts of treated plants (pressed and dried) to the informants, this proposal demands less time than the previous one; however, there are some disadvantages like the loss and changes in color and smell; and (c) Photographs are representations of plants in their natural habitat, without the need to go out into the field. However, 
this method restricts identification only by sight, not considering the smell and taste. Moreover, Ferreira et al. (2011) [3] mentioned the use of photographs as a facilitator in the identification of species researched in a community in northeastern Brazil. Another example of visual stimulation includes (d) fresh plants, the stimuli offered is part of the plant whose characteristics are maintained. A disadvantage to using visual stimuli is the lack of plant material during the interview or consistently collecting plant material for the various moments with all the informants $[2,4]$.

In general, the use of visual stimuli applied to the ethnobotanical research has been applied more frequently by researchers because of its use as an auxiliary tool in the process of gathering information [2, 5]. In a study done in Caruaru, in northeastern Brazil, Monteiro et al. (2006) [5] researched two useful plants in two rural communities and started the interviews using the checklist/inventory method [6], which consisted in offering photographs of the species pertinent to the research. The authors found that no more than 5\% of informants recognized a species from the stimuli offered. The interview could only proceed when the name of the species was pronounced. In comparing photographs with dried specimen and its efficiency with informants, Thomas et al. (2007) [7] found that on average the photographs were recognized by $94 \%$ of informants in comparison to the $77 \%$ recognition of dried specimens. Thus, the use of photographs in ethnobotanical research has presented distinct results. Intercultural factors like gender, age, or educational level can influence the use of visual stimuli. Case et al. (2005) [8] in Papua New Guinea, perceived issues with the identification of plants via photographs, especially with older informants. These authors found that this could be due to visual problems caused by old age. Garcia (2006) [9] verified that women from Pniya and Kuruma, India, did not identify plants from photographs. Therefore, research that seeks to clarify this information is necessary. Furthermore, the present study prioritized verifying the efficiency of photographs of two species largely used in local therapy, the Amburana cearensis (Allemao) A. C. Sm, and Lafoensia replicata Pohl., as visual stimuli. Additionally, this study investigated the differences between age, education, and gender in reference to the recognition of the stimuli and traditional recognition of the two species in the community of Santo Antonio, Currais, Piauí, northeastern Brazil.

\section{MATERIALS AND METHODS}

\subsection{Selection of the species and study area}

Two tree species were chosen for their large importance in traditional medicine, the amburana [Amburana cearensis (Allemao) A. C. Sm] and mangabeira (Lafoensia replicata Pohl.). The plant species were identified in situ accompanied by a forest guide, and botanical material was collected for identification. The plants were herborized and incorporated into the Herbário Graziela Barroso (TEPB), Universidade Federal do Piauí. The collections were done in a vegetation similar to that of the community of Santo Antônio.

The study area is the community of Santo Antônio, previously called Boca da Caatinga, belonging to the municipality of Currais, located in southern Piauí state, in the region of Médio Gurguéia, bordering the municipality of Palmeira to the north, municipality of Bom Jesus to the south, Santa Luz to the east, and Baixa Grande do Ribeiro to the west. The community is located $640 \mathrm{~km}$ from the capital Teresina and has approximately 4,939 inhabitants [10]. The climate in this region has a well defined dry summer season, influenced by a circulation mechanism of air masses, and the winter season has concentrated rain showers. The vegetation is composed of trees and short, twisted, dense bushes, that are dry in the summer with small deciduous leaves, presenting deep and thick roots, a predominant characteristic of the caatinga [11, 12]

The community of Santo Antônio is composed of 34 families, living in small clay or masonry houses, with small businesses, and one church. They rely on a team from the Programa Saúde da Família (Family Health Program), that visit the community once a month, directing the more serious cases to the municipality of Bom Jesus and afterwards to the capital Teresina. The residents of the community are of rural origin, where $90 \%$ of the people survive from agricultural production and Bolsa Família, a family welfare program created by the Federal Government. The other 10\% of the population are small business owners and public workers for the municipality. Principally 
the community plants, maintains, and harvests corn, beans, rice, cassava, and some vegetables that are sold at the local markets.

\subsection{Ethnobotanical data collection and analysis.}

First, informational visits to the community were conducted in order to establish a rapport and a friendly relationship with the interviewees. The division of fieldwork [13] allowed the addition of information between distinct seasons of the year, as well as bridging the gap with the previous trips, for example, interviews with informants that were not present at the time of the visit.

All the informants over 18 years old were invited to participate. Thus, they were informed of all of the objectives of the study and received a free and informed consent form to sign, giving their permission to complete the research in accordance with the current resolution [14]. The work was submitted and approved by the Research Ethics Committee from the Universidade Federal do Piauí (CAAE: 46264515.0.0000.5214).

Semi-structured interviews were conducted and began with the checklist/interview [2] method. A sample of a visual resource that consisted of a board with a sharp high resolution photo montage on A4 sized paper of the two plants was presented showing the whole plant, the bark, leaves, flower, and fruit. A visual resource was made for each species. If the informant did not recognize the species, the interviewer noted the result and mentioned the popular name so the interview could proceed. Everyone recognized the plants when provided with the popular name. Afterwards, information about the use, preparation, area of harvest, and parts harvested were collected. From these questions the local knowledge was analyzed through quantitative measurements to analyze the consensus between the informants on the objectives of the proposal $[5,15]$ (Table 1).

Table 1. Knowledge measurements for two tree species used in local therapy [Amburana cearensis (Allemao) A. C. Sm and Lafoensia replicata Pohl.] in the community of Santo Antônio, Currais, Piauí. Proposed by Byg and Baslev (2001) [15].

\begin{tabular}{l|l|l}
\hline Index & Calculation & Description \\
\hline $\begin{array}{l}\text { Informant diversity value } \\
\text { (VDI) }\end{array}$ & $\begin{array}{l}\text { VDI = no. of uses cited by each } \\
\text { informant divided by the number } \\
\text { of total uses. }\end{array}$ & $\begin{array}{l}\text { Measures how many informants } \\
\text { use the species and how this use } \\
\text { is distributed. }\end{array}$ \\
\hline $\begin{array}{l}\text { Informant equitability } \\
\text { value (VEI) }\end{array}$ & $\begin{array}{l}\text { VEI = value of the diversity of } \\
\text { the informant divided by the } \\
\text { maximum value of the referred } \\
\text { index. }\end{array}$ & $\begin{array}{l}\text { Measures the homogeneity of } \\
\text { the informant's knowledge. }\end{array}$ \\
\hline
\end{tabular}

Statistical differences between the indexes were verified with the Kruskal-Wallis Test at a 5\% probability. To analyze whether gender, education, and/or age influences the recognition of species when using the stimuli, a $2 \times 2$ table was made representing the combination of responses between the first and second group of interviewees. The combination of responses formed two paired and correlated samples and were submitted to the contingency table for Fisher's Exact Test to analyze the significance of the differences [16].

\section{RESULTS AND DISCUSSION}

\subsection{Ethnoknowledge of two medicinal tree species in the community of Santo Antônio, Currais, Piauí.}

Twenty-eight informants, 15 females (54\%) and 13 males (46\%), were interviewed concerning therapeutic indications for the studied species. The other six families were not at the site during our visit.

In the present study, a total of 16 uses were cited for amburana (A. cearenses) and ten for mangabeira (L. replicata) (Table 1). In a study conducted by Baptistel et al. (2014) [17] in the same community, mangabeira ( $L$. replicata) had 11 cited uses (there was an increase in cited uses for prostate problems) and amburana (A. cearenses) had the same quantity of cited uses as the present 
study. Thus, this domain-specific information is important in emphasizing both species, since they are scarce in documents from the region and further support would allow for future proposals of appropriate local management.

Table 2. Therapeutic indications, parts used, and applications of two tree medicinal species in the community of Santo Antonio, Currais, Piauí.

\begin{tabular}{l|c|l}
\hline $\begin{array}{l}\text { Common name } \\
\text { (Scientific name) } \\
\text { Voucher }\end{array}$ & Part used & \multicolumn{1}{|c}{ Therapeutic indications } \\
\hline $\begin{array}{l}\text { Amburana } \\
\text { [Amburana cearensis } \\
\text { (Allemao) A. C. Sm.] }\end{array}$ & $\begin{array}{c}\text { Bark and } \\
\text { seeds }\end{array}$ & $\begin{array}{l}\text { Anti-inflammatory, intestinal colic, flu, } \\
\text { stomachache, snake bite, diarrhea, migraine, } \\
\text { emetic, headache, joint pain, dizziness, fever, } \\
\text { constipation, depurative, diuretic, kidney infection. }\end{array}$ \\
\hline $\begin{array}{l}\text { Mangabeira } \\
\text { (Lafoensia replicata }\end{array}$ & Bark & $\begin{array}{l}\text { Fatigue, wound healing, anti-diarrheal, anti- } \\
\text { inflammatory, digestive, body aches, gastritis, liver } \\
\text { Pohl.) }\end{array}$ \\
29.623
\end{tabular}

For amburana (A. cearenses) the seeds were cited more frequently as the part used in local therapy, and for a mangabeira (L. replicata), there was consensus on the indication of barks for cures. Many useful native plants from the northeastern semiarid have bark peels that are collected and marketed in public markets and fairs, where they are indicated as curative due to the high levels of phenolic compounds from secondary metabolites, specifically tannins, which supports the knowledge and indication of plants in local treatments. Monteiro et al. (2014) [18] found 7.2\% and $4.3 \%$ of total tannins in the bark of $L$. replicata and A. cearensis, respectively, supporting the indications for use. Many trees are used as medicinal plants, with only the bark being attributed to their healing power $[5,19]$. These plants are subjected to aggressive bark collection and can form a ring, a practice that fatally affects the plant. Moreover, these most popular tree species have both a slow growth and reproduction [19], which also happens with many other medicinal plants from the Caatinga. Leaves, fruits, or seeds can be an important substitute for local therapy, thereby decreasing the local and aggressive collection pressure around these barks.

There are some studies in scientific literature that support the therapeutic indications of some traditionally important plants. A search of $A$. cearensis found hepatoprotective activity in rats treated with the bark extract [20]. The authors also showed that this plant is well known and used for treating respiratory disorders in northeastern Brazil [20]. The bark of the amburana or cumaru stem, as the species is also known, showed good activity for the treatment of Alzheimer's disease [21]. Moraes et al. (2005) [22] presented a plant list with their respective indications used by the indigenous of Tapeba, Ceará, among which A. cearensis is emphasized. Furthermore, phenolic glycosides were found in the bark of $A$. cearensis, which has antimalarial and bactericidal activity [23].

In regards to mangabeira (L. replicata) no studies on biological activity were found to support its therapeutic indications. However, there are some studies on the use and biological activity of Lafoensia pacari A. St.-Hil. [17, 18, 24, 25, 26, 27). The antibacterial activity of $L$. pacari A. St.Hil. was verified and showed that $96.4 \%$ of the lineages used were susceptible to plant leaf extracts [27]. Galdino et al. (2009) [25] found antidepressant activity in rats from the ethanolic extract from L. pacari A. St.-Hil. The authors reported that depression is one of the most significant health issues of today, according to the Brazilian Psychiatric Association, and thus the search for new compounds is necessary. In a study focusing on cerrado plants, Lima et al. (2015) [28] tested activity against promastigote forms of Leishmania amazonensis and found that the hydroalcoholic extract of $L$. pacari A. St.-Hil showed significant leishmanicidal activity, confirming its efficacy. Thus, the importance of further studies on the phytochemistry and biological activities of these species is important, especially for L. replicata, since several indications of therapeutic uses for the species were shown here. 
Table 3. Knowledge measurements for two species used in local therapy [Amburana cearensis (Allemao)

A. C. Sm e Lafoensia replicata Pohl.] in the community of Santo Antônio, Currais, Piauí.

\begin{tabular}{l|c|c}
\hline \multicolumn{1}{c|}{ Amburana cearensis (Allemao) A. C. Sm. } & Lafoensia replicata Pohl. \\
\hline Measurements & Mean \pm standard deviation & Mean \pm standard deviation \\
\hline Total VDI & $0.14 \pm 0.05^{\mathrm{a}}$ & $0.19 \pm 0.08^{\mathrm{b}}$ \\
\hline Total VDI Females & $0.13 \pm 0.05$ & $0.18 \pm 0.08$ \\
\hline $\begin{array}{l}\text { VDI Females }<40 \\
\text { years }\end{array}$ & $0.13 \pm 0.05^{\mathrm{a}}$ & $0.20 \pm 0.08^{\mathrm{b}}$ \\
\hline $\begin{array}{l}\text { VDI Females } \geq 40 \\
\text { years }\end{array}$ & $0.14 \pm 0.05$ & $0.18 \pm 0.08$ \\
\hline Total VDI Males & $0.14 \pm 0.05$ & $0.18 \pm 0.08$ \\
\hline $\begin{array}{l}\text { VDI Males }<40 \\
\text { years }\end{array}$ & $0.13 \pm 0.01$ & $0.20 \pm 0.08$ \\
\hline $\begin{array}{l}\text { VDI Males } \geq 40 \\
\text { years }\end{array}$ & $0.14 \pm 0.05$ & $0.18 \pm 0.08$ \\
\hline
\end{tabular}

\begin{tabular}{l|c|c}
\hline Total VEI & $0.03 \pm 0.01$ & $0.05 \pm 0.02$ \\
\hline Total VEI Females & $0.03 \pm 0.01$ & $0.05 \pm 0.02$ \\
\hline $\begin{array}{l}\text { VEI Females < 40 } \\
\text { years }\end{array}$ & $0.03 \pm 0.01$ & $0.05 \pm 0.02$ \\
\hline $\begin{array}{l}\text { VEI Females } \geq 40 \\
\text { years }\end{array}$ & $0.03 \pm 0.01$ & $0.05 \pm 0.02$ \\
\hline Total VEI Males & $0.03 \pm 0.01$ & $0.05 \pm 0.02$ \\
\hline $\begin{array}{l}\text { VEI Males < 40 } \\
\text { years }\end{array}$ & $0.03 \pm 0.01$ & $0.05 \pm 0.02$ \\
\hline $\begin{array}{l}\text { VEI Males } \geq 40 \\
\text { years }\end{array}$ & $0.03 \pm 0.01$ & $0.05 \pm 0.02$ \\
$\begin{array}{l}\text { Values followed by distinct letters in the same line differ significantly for the Kruskal-Wallis test at } 5 \% \\
\text { probability. }\end{array}$
\end{tabular}

In the studied community, informants cited on average 2.2 uses for A. cearensis and 1.8 uses for L. replicata. The differences observed in the total informant diversity (VDI) are significant for both species (Table 3), demonstrating that the knowledge presented about the uses of A. cearensis was more expressive. The same result was found for younger women among the species. Most likely amburana (A. cearensis) has a more prominent importance in the studied community. This result, although found only between two indices (total VDI and VDI women < 40 years), can be supported by the current interest of researchers in the two plant species studied here. Amburana (A. cearensis) has numerous elucidative studies on its biological activity, while no studies have been found for mangabeira (L. replicata).

The other comparisons were not significant at the 5\% probability level (Table 3 ). Regarding the homogeneity of knowledge between species, calculated by equitability (VEI), we found that among the informants of this community there is no local expert, that is, one or some contributed with the largest amount of uses over others. Moreover, the plant knowledge in the community of Santo Antonio, Piauí seems to be homogenously shared among all informants. This pattern is repeated when considering only the knowledge of women and men alone.

Other studies have also used quantitative indices to analyze and discuss accumulated knowledge on useful native vegetation $[5,15,29,30]$. These values may reflect people's preferences, and thus, suggests a strong collection and pressure on some useful species. Therefore, local collection practices should be given special care, and the development of conservation and sustainable collection strategies is strongly recommended [29]. 


\subsection{Use of photographs as visual stimuli for the recognition of two species in the community of Santo Antônio, Currais, Piauí}

There were no distinctions for recognizing the visual stimuli of the two species when considering all informants (Table 4). There was no significant difference between the recognition of visual stimuli between genders and between education levels (Table 4). Thus, the visual stimuli used (photographs) were not efficient for this study, since there was no distinction between those who recognized and those that did not recognize the stimuli, when taking gender and education into consideration.

Table 4. Recognition of two medicinal plant species through visual stimuli taking education and gender into consideration in the community of Santo Antonio, Currais, Piauí.

\begin{tabular}{l|l|l|c}
\hline \multicolumn{2}{c|}{} & $\begin{array}{l}\text { Amburana } \\
\text { A. cearensis } \\
\text { (Allemao) A. C. Sm. }\end{array}$ & $\begin{array}{l}\text { Mangabeira } \\
\text { L. replicata } \\
\text { Pohl. }\end{array}$ \\
\hline \multirow{2}{*}{ All informants } & Recognized & 15 & 12 \\
\cline { 2 - 4 } & Not recognized & 13 & 16 \\
\hline \multirow{2}{*}{$\begin{array}{l}\text { Males } \\
\text { Females }\end{array}$} & Recognized & 9 & 5 \\
\cline { 2 - 4 } & Not recognized & 4 & 8 \\
\hline \multirow{2}{*}{$\begin{array}{l}\text { Illiterate } \\
\text { Incomplete elementary } \\
\text { and junior high school }\end{array}$} & Recognized & 6 & 6 \\
\cline { 2 - 4 } & Not recognized & 9 & 9 \\
\cline { 2 - 4 } & Recognized & 5 & 3 \\
\cline { 2 - 4 } & Not recognized & 2 & 8 \\
\hline
\end{tabular}

The above values do not differ significantly for Fisher's Exact Test at 5\% probability.

Monteiro et al. (2006) [5], in Caruaru, Pernambuco, researched useful plants in two rural communities and started interviews using the checklist/inventory method [6], which consisted of offering a visual resource, photos of the target species of the research. The authors reported that no more than 5\% recognized the different species by the stimuli offered. The interview could only proceed when the species name was pronounced. Case et al. (2005) [8], in Papua New Guinea, also noticed problems with the identification of plants by photographs, especially with older informants. These authors showed that this may be due to visual problems caused by age. Garcia (2006) [9] found that women from Paniya and Kuruma, India did not identify plants by photographs. In an entomological fauna study in the state of Sergipe, Brazil, Lima et al. (2016) [31] compared entomological boxes and photographs as visual stimuli and found that the boxes were more efficient.

However, trying to compare photographs with dried specimen, in terms of their efficiency with informants, Thomas et al. (2007) [7] found that photographs were recognized by $94 \%$ of informants, on average, compared to $77 \%$ recognition using dried specimen. In regards to using dried specimen as visual stimuli, Santos et al. (2011) [32] found that at least one informant recognized $91 \%$ of the plants offered. These authors realized that there are no groups of plants with high recognition and stated that plants not mentioned in the interviews were not recognized by either stimulus. On the other hand, Medeiros et al. (2008) [33], researching plants used as fuel in Caruaru, northeastern Brazil, applied semi-structured interviews also using pieces of plant stem as stimuli and found about 34\% recognition. In addition, Miranda et al. (2007) [34] mentioned that the location of the research can greatly influence the interviews because of the visual stimuli. For example, lists of useful plants mentioned by herbalists in their stores may have a higher number compared to the list collected at their home. 
Table 5. Recognition through visual stimuli for two medicinal plant species taking into consideration age in the community of Santo Antonio, Currais, Piauí.

\begin{tabular}{|c|c|c|c|c|c|}
\hline & \multicolumn{2}{|c|}{$\begin{array}{c}\text { Amburana } \\
\text { A. cearensis (Allemao) A. } \\
\text { C. Sm. }\end{array}$} & \multicolumn{2}{|c|}{$\begin{array}{l}\text { Mangabeira } \\
\text { L. replicata } \text { Pohl. }\end{array}$} \\
\hline & & Recognized & $\begin{array}{c}\text { Not } \\
\text { recognized }\end{array}$ & Recognized & $\begin{array}{c}\text { Not } \\
\text { recognized }\end{array}$ \\
\hline \multirow{2}{*}{$\begin{array}{l}\text { All } \\
\text { informants }\end{array}$} & Older than 40 & 10 & 11 & 10 & 11 \\
\hline & $\begin{array}{l}\text { Younger or } \\
\text { equal to } 40\end{array}$ & 5 & 2 & 2 & 5 \\
\hline \multirow[t]{2}{*}{ Males } & Older than 40 & 8 & 2 & 5 & 5 \\
\hline & $\begin{array}{l}\text { Younger or } \\
\text { equal to } 40\end{array}$ & 2 & 1 & - & 3 \\
\hline \multirow[t]{2}{*}{ Females } & Older than 40 & $2^{\mathrm{a}}$ & $9^{b}$ & 5 & 6 \\
\hline & $\begin{array}{l}\text { Younger or } \\
\text { equal to } 40\end{array}$ & 4 & - & 2 & 2 \\
\hline
\end{tabular}

Values followed by distinct letters in the same line differ significantly for Fisher's Exact Test at a 5\% probability.

Similar to gender and educational level, the age of informants did not prove to be an important factor in the recognition when using visual stimuli (Table 3). An exception was recorded for the stimuli used to recognize amburana (A. cearensis) for women over the age of 40, whose nonrecognition was significant (Table 5). Thus, the results of this research showed that sociocultural factors did not strongly influence the recognition of stimuli. Medeiros et al. (2008) [33] demonstrated that there are some factors for non-recognition of plant photographs known by informants, such as disability, poor contact with photographs, visual problems among older people, or the quality of the photographs presented.

In terms of distinctions in knowledge between age or gender, some authors have already shown their results and viewpoints [5, 35, 36, 37, 38]. For men, work is directed outside the residence [39] and also implies the use of physical force, such as timber use in construction [37]. According to Voeks (2007) [40], women stood out regarding the use of therapeutic plants, which may be due to experiences with backyard management and treatment of family members, and close people via herbal medicine. Paodjuenas et al. (2019) [38] also described this prominence in a study with umbuzeiro (Spondias tuberosa Arruda) in rural communities of Paraíba. The authors found a higher number of citations among women for medicinal and food indications of plants. In contrast, other research has not found such distinctions between men and women [17, 18, 41]. Giraldi and Hanazaki (2010) [41] in the Sertão do Ribeirão, Santa Catarina, found that gender did not influence the research, but the authors specified that this result can be explained due to the low number of interviews conducted. Baptistel et al. (2014) [17] interviewed 32 people in an ethnobiological study in southern Piauí and found no distinctions between genders regarding knowledge about medicinal plants. In the Riachão, Caruaru, northeastern Brazil, Monteiro et al. (2006) [5] conducted a survey of two useful species (Myracrodruon urundeuva Allemão and A. colubrina Vell. Brenam.) and found distinctions between knowledge for gender and age. Older women showed greater diversity of knowledge on the uses of M. urundeuva (aroeira) when compared to younger men. Moreover, they also stated that the homogeneity of this knowledge, expressed by equitability, was significantly higher. The same was true when the comparison was made between men of different ages for the same species, with older men being more knowledgeable. The other comparisons were not significant at the $5 \%$ probability level.

\section{CONCLUSION}

According to the results presented, the selected visual stimuli was inefficient regarding the recognition of the two species (L. replicata and A. cearensis) in the studied community. According to Medeiros et al. (2010) [2] these photographs have the advantage of being able represent the plant in its natural habitat, without having to go into the field. However, they restrict identification only 
by sight, excluding smell, texture, and taste, for example. Future studies aimed at comparing more techniques (various types of stimuli) associated with a larger sample amplitude (community comparison) may elucidate these questions more accurately, as there are controversial results in the available literature.

Moreover, the results obtained, even considering the knowledge of only two species, may add to the information provided about the specific domain of knowledge related to medicinal plants, since the selected species are very popular in the region. This approach can be very beneficial in rapid inventories for a quantitative assessment of local knowledge for the purposes of conservation and management of local biodiversity, as it allows for a panoramic design of how these resources are understood and locally valued.

\section{ACKNOWLEDGMENTS}

The authors would like to thank the residents of the community of Santo Antônio who agreed to contribute to this study.

\section{BIBLIOGRAPHICAL REFERENCES}

1. Albuquerque UP, Nascimento ALB, Soldati GT, Feitosa IS, Campos JLA, Hurrell JA, Hanazaki N, Medeiros PM, Silva RRV, Ludwinsky RH, Ferreira Junior WS, Reyes-García V. Ten important questions/issues for ethnobotanical research. Acta Bot Bras. 2019; doi: 10.1590/0102-33062018abb0331

2. Medeiros PM, Almeida ALS, Lucena RFP, Souto FJB, Alburqueque UP. Uso de estímulos visuais na pesquisa etnobiológica. In Albuquerque UP, Lucena RFP, Cunha LVFC (Eds.) Métodos e técnicas na pesquisa etnobiológica e etnoecológica. NUPEEA, Recife. 2010. pp. 41-61.

3. Ferreira WS, Siqueira CF, Albuquerque UP. Plant Stem Bark Extractivism in the Northeast Semiarid Region of Brazil: A New Aport to Utilitarian Redundancy Model. Evid Based Complement Alternat Med. 2012;2012:543207. doi: 10.1155/2012/543207.

4. Griffin D. Contributions to the Ethnobotany of the Cup'it Eskimo, Nunivak Island, Alaska. J Ethnobiol. 2001; 21(2):91-132.

5. Monteiro JM, Albuquerque UP, Lins-Neto EMF, Araújo EL, Amorim ELC. Use patterns and knowledge of medicinal species among two rural communities in Brazil's semi-arid northeastern region. $\mathrm{J}$ Ethnopharmacol. 2006;105:173-186.

6. Mutchnick PA, McCarthy BC. 1997. An ethnobotanical analysis of the tree species common to the subtropical moist forest of the Peten, Guatemala. Econ Bot. 1997;51(2):158-183.

7. Thomas E, Vandebroek, I, Van Damme P. What works in the field? A comparison of different interviewing methods in ethnobotany with special reference to the use of photographs. Econ Bot. 2007;61(4):376-384.

8. Case RJ, Pauli GF, Soejarto DD. Factors in maintaining indigenous knowledge among ethnic communities of Manus Island. Econ Bot. 2005;59(4):356-365.

9. Garcia GFC. 2006. The mother - child nexus. Knowledge and valuation of wild food plants in Wayanad, Western Ghats, India. J Ethnobiol Ethnomed. 2006;2:39-45.

10. Instituto Brasileiro de Geografia e Estatística (IBGE) (2019) Disponível em < https://cidades.ibge.gov.br/brasil/pi/currais/panorama > Acessado em: 08 maio de 2019.

11. Emperaire L. Végetation et gestion des resources naturelles dans la caatinga du sudest du Piauí (Brésil). Doctorat d'Etat ès Sciences Naturelles. Université Pierre et Marie Curie, Paris. 1989.

12. Rodal MJN, Sampaio EVSB. A vegetação do bioma caatinga. In Sampaio EVSB, Giulietti AM, Virgínio J, Gamarra-Rojas CFL. Vegetação e flora da caatinga. pp. 11-25. APNE - CNIP. 176p. 2002.

13. Titiev M. Introdução à antropologia cultural. Lisboa: Fundação Calouste Gulbenkian. 2002.

14. Albuquerque UP, Lucena RFP, Alenacar NL. Métodos e técnicas para coleta de dados etnobiológicos. In Albuquerque UP, Lucena RFP, Cunha LVFC (Eds.) Métodos e técnicas na pesquisa etnobiológica e etnoecológica. NUPEEA, Recife. 2010. pp. 41-61.

15. Byg A, Baslev H. Diversity and Use of Palms in Zahamena, Eastern Madagascar. Biodiver Conserv. 2001;10:951-970.

16. Zar JH. Biostatistical Analysis. 5th Edition. Prentice Hall. 2010.

17. Baptistel AC, Coutinho JMCP, Lins Neto EMF, Monteiro JM. Plantas medicinais utilizadas na Comunidade Santo Antônio, Currais, Sul do Piauí: um enfoque etnobotânico. Rev Bras Plantas Med. 2014;16(2):406-425. 
18. Monteiro JM, Souza JSN, Lins Neto EMF, Scopel K, Trindade EF. Does total tannin content explain the use value of spontaneous medicinal plants from the Brazilian semi-arid region? Rev Bras Farmacogn. 2014;24:116-123.

19. Zschocke S, Rabe T, Staden j. Plant part substitution - a way to conserve endangered madicinal plants? J Ethnopharmacol. 2000;71:281-292.

20. Leal LKAM, Pereira FA, Kirley MC, Cícero FBF, Fontenele JAB, Pitombeira MV, Edilberto RS, Viana GSB. Protective Effects of Amburoside A, a Phenol Glucoside from Amburana cearensis, against $\mathrm{CCl}_{4}{ }_{-}$ Induced Hepatotoxicity in Rats. Planta Med. 2008;74(5):497-502.

21. Trevisan MTS, Macedo FVV. Seleção de plantas com atividade anticolinasterase para tratamento da doença de alzheimer. Quim Nova. 2003;26:301-304.

22. Morais SM, Dantas JP, Silva ARA, Magalhães ER. Plantas medicinais usadas pelos índios Tapebas do Ceará. Rev Bras Farmacogn. 2005;15:169-177

23. Bravo B, José A, Sauvain, M. Bioactive phenolic glycosides from Amburana cearensis. Phytochemistry. 1999;50:71-74.

24. Solon S, Lopes L, Sousa Jr., PT, Schmeda-Hirschmann G. Free radical scavenging activity of Lafoensia pacari. J Ethnopharmacol. 2000;72:173-178.

25. Galdino PM, Nascimento MVM, Sampaio BL, Ferreira RN, Paula JR, Costa EA. Antidepressant-like effect of Lafoensia pacari A. St.-Hil. ethanolic extract and fractions in mice. J Ethnopharmacol. 2009;124:581-585.

26. Guimarães HA, Nascimento MVM, Tavares A, Galdino PM, Paula JR, Costa EA. Effects of ethanolic extract of leaves of Lafoensia pacari A. St.-Hil., Lythraceae (pacari), in pain and inflammation models. Rev Bras Farmacogn. 2010;20(3):328-333.

27. Porfírio Z, Melo Filho GC, Alvino V, Lima MRF, Sant'Ana AEG. Atividade antimicrobiana de extratos hidroalcoólicos de Lafoensia pacari A. St.-Hil., Lythraceae, frente a bactérias multirresistentes de origem hospitalar. Rev Bras Farmacogn. 2009;19(3):785-89.

28. Lima PC, Santos MG, Calabrese KS, Silva ALA, Almeida F. Avaliação da capacidade leishmanicida de espécies vegetais do cerrado. Rev Patol Trop. 2015;44(1):45-55.

29. Feitosa IS, Albuquerque UP, Monteiro JM. Knowledge and extractivism of Stryphnodendron rotundifolium Mart in a local community of the Brazilian Savanna, Northeastern Brazil. J Ethnobiol Ethnomed. 2014;64:1-13.

30. Brito MFM, Lucena RFP, Dias DC. Conhecimento etnobotânico local sobre plantas medicinais: uma avaliação de índices quantitativos. Interciencia. 2015;40(3):156-164.

31. Lima DCO, Ramos MA, Silva HCH, Chaves AGA. Rapid assesment of insect fauna based on local knowledge: comparing ecological and ethnobiological methods. J Ethnobiol Ethnomed. 2016; doi:10.1186/s13002-016-0085-z.

32. Santos LL, Ramos MA, Silva VA, Albuquerque UP. The use of visual stimuli in the recognition of plants from anthropogenic zones: evaluation of the checklist-interview method. Sitientibus 2011;11(2):231-237.

33. Medeiros PM, Almeida ALS, Ramos MA, Albuquerque UP. A variation of checklist interview tecnich in the study of firewood plants. Func Ecosyst Commun. 2008;2:45-50.

34. Miranda TM Amorozo, MCM, Govone JS, Miranda DM. The Influence of Visual Stimuli in Ethnobotanical Data Collection Using the Listing Task Method. Field Methods. 2007;19(1):76-86.

35. Voeks RA, Nyawa S. Healing flora of the Brunei Dusun. Borneo Res Bull. 2001;32:178-195.

36. Voeks RA, Leony A. Forgetting the forest: assessing medicinal plant erosion in eastern Brazil. Econ Bot. 2004;58:294-306.

37. Torres-Avilez W, Nascimento ALB, Campos LZO, Silva FS, Albuquerque UP. Gênero e idade. In: Albuquerque UP. Introdução a etnobiologia. NUPEEA, Recife, 189 p. 2014.

38. Paodjuenas Costa GM, Nunes EN, Paulino FO, Lucena RFP. Conhecimento tradicional e usos do umbuzeiro (Spondias tuberosa Arruda) por comunidades rurais do semiárido, Paraíba, Nordeste, Brasil. Ethnoscientia. 2019;4, doi: 10.22276/ethnoscientia.v 4, 1199.

39. Lucena CM, Costa GM, Souza RF, Carvalho TKN, Marreiros NA, Alves CAB, Pereira DD, Lucena RFP. Conhecimento local sobre cactáceas em comunidades rurais na mesorregião do sertão da Paraíba (Nordeste, Brasil). Biotemas. 2012;25:281-291.

40. Voeks RA. Are women reservoirs of traditional plant knowledge? Gender, ethnobotany and globalization in northeast Brazil. Singapore J Trop Geograp; 2007;28:7-20.

41. Giraldi M, Hanazaki N. Uso e conhecimento tradicional de plantas medicinais no Sertão do Ribeirão, Florianópolis/SC, Brasil. Acta Bot Bras. 2010;24:395-406. 